\title{
Planning and Management Issues and Challenges of Flash Flooding Disasters in Saudi Arabia: The Case of Riyadh City
}

\author{
Tahar A. Ledraa \\ Department of Urban Planning, King Saud Univer- \\ sity Riyadh Saudi Arabia \\ tledraa@ksu.edu.sa
}

\author{
Ali M. Al-Ghamdi \\ Department of Geography, King Saud University \\ Riyadh Saudi Arabia \\ aghamdi1@ksu.edu.sa
}

(Received 19/5/2018; accepted for publication 23/5/2019.)

\begin{abstract}
The paper sets out to unravel the issues and challenges in flash flood disaster management in Saudi Arabia, through Riyadh city as an example. The issue of flooding management and planning has been brought to the forefront of government agenda as a result of rising frequencies and intensities of flash floods in the country. It discussed specific issues, explaining what is lacking and what should be done to deal effectively should such an unfortunate event occur. The main challenging issues found are: 1) Disaster management in the Saudi context is still primarily a matter of response and relief operations as it does not include any proactive or preventive provisions against the devastating impacts of disasters; 2) Current management approach of disaster focusses predominantly on disaster containment rather than management; 3) Local authorities do not have well-defined disaster management strategies supported by clearly defined action plans; and 4) Data and mapping technologies (e.g., GIS) are not a priority nor well appreciated as an effective decision tool in disaster management. Accordingly, the paper proposes adapting a comprehensive integrated management approach that adheres to the well-known four disaster management stages, and that ensures public participation, flexibility, transparency, production, accountability and effectiveness. It also proposes establishing well-equipped civil disaster and emergency management centres capable of collecting, storing and handling all the data about such events, hence facilitating analysis, modelling and disseminating information to all concerned parties. The local community should also be effectively involved in the whole management process.
\end{abstract}

Keywords: Disaster management, Flash Flood, Emergency, Community Participation, Mapping, Participatory GIS.

\section{Introduction and Problem Statement}

Being an arid region, Saudi Arabia has two short rainy seasons. The first extends from mid-October to mid-December, whereas the seond ranges from late March to late May. Its climate is characterized with fluctuating low rainfall of an annual average of about $150 \mathrm{~mm}$ (Ministry of Higher Education, 2015, p. 68). Even though it has no permanent year-round rivers, the coutry is not immune to flash flooding disasters whose frequency and severity are increasing.
Flash flooding caused by intense rainfall is the most common type in Saudi Arabia. Riverine flooding is not very common as there is no running rivers in this arid region. Flash flooding has some quite striking differences compared to riverine flooding. It is quite difficult to predict and can happen all of a sudden at any time of the year. It is localized and gives little or no lead-time to issue warnings. Flash flood waters travel like waves, flow at high speed, have no predetermined path, and contain a high debris load, and therefore causing a lot of daage to city infrastructures, property and 
economic assets, and even loss oflife. It is precisely for these characteristics that flash flooding represents a challenge for both government and non-government organizations (NGOs). Riverine flood on the cotrary, is predictable and has a much longer lead-time.

In the last decade alone, the Kingdom witnessed several flash flooding disasters that affected thousands of people and caused an unprecedented scale of human and economic losses. In 2009, a flash flood swept most of Jeddah city resulting in more than 163 dead, hundreds of injured, thousands of rescued persons, and many more thousands of damaged properties and economic assets (Alamri, 2010). The city recorded $150 \mathrm{~mm}$ of torrential rainfall within the span of 4 hours only, an amount that has not been seen for the past quarter of a century (Almazroui 2011; Haggag and El-Badry, 2013; Almazroui, 2013; Al-Khalaf and Basset, 2013). The volume of rain water poured down has been roughly estimated at about 6 to 9 billion cubic meters, which is the equivalent to half the total annual water consumption in Saudi Arabia (Al-Ala$\mathrm{mi}, 2011)$. In 2011, a wave of torrential rain $(50 \mathrm{~mm}$ in four hours) resulted in 10 dead and 114 injured, as well as thousands of damaged buildings, let alone the economic losses that have been estimated at billions of dollars (Almazroui, 2013). In November 2013, the city of Riyadh experienced a heavy rainfall of $32.2 \mathrm{~mm}$ within hours, causing a flash flood that resulted in some deaths and devastation to many properties located in risk-prone areas of the city (Ledraa, and Al-Ghamdi, 2014). In the last week of November 2015 in Jeddah, a 22 $\mathrm{mm}$ of torrential rain totally disrupted life in the city, interrupted businesses, closed schools and universities, and people were asked to stay indoors (Gulf News, 2015). These events indicate that cities in Saudi Arabia are not yet properly prepared in terms of disaster management, response and civil defense.

Flash flood disasters in Saudi Arabia will continue to be an important research subject since: 1) They are the predominant type of natural disasters in the country; 2) Their occurrences appeared to increase lately with an unprecedented pace; and 3) They caused severe devastations to properties and serious disruptions to economic activities. In examining the available data, A UN study, reported in iNews Arabia, indicated that natural disasters at the global level have doubled since 1980, while in the Middle East and north Africa the increase has been threefold
(iNewsArabia, 2013). Based on this account and given the vulnerability and exposure to such disasters, a recent publication by Ledraa and Al-Ghamdi (2014) dealt with this issue from a normative standpoint. The present paper examines the current practices in disaster management in general and specifically to unravel the main challenges and issues that we still think need a closer investigation as to the flash flood disaster management. The paper will closely examine various management issues associated with flash flood disasters within the Saudi context with focus on Riyadh city as a case study. To overcome the issue of data scarcity related to flash flooding and its management in Riyadh, the authors adopted a descriptive analytic method of investigation. Our critical discussion approach is based on information and results from various local reference materials and interviews with few civil defense officials and other stakeholders involved with the issue of hazard risk reduction interventions and some concerned populations. To further support our discussion, we utilized mapping technology to illustrate few points, as well as cross-referencing the highlighted issues with related literature in this field, including international and local reports and few available summary meeting minutes as reported in the media.

\section{Overview of Major Issues and Challenges}

\subsection{The issue of Legislation and definition}

The first issue lies with how the authority responsible for dealing with disaster management in Saudi Arabia is organized. The General Directorate of Civil Defense (GDCD) mandate includes legislation, regulation, coordination with various government institutions, and implementation. In each of the thirteen administrative regions of the country, there is a Local Civil Defense Department (LCDD) and a Local Emergency Committee (LEC) whose main objective is to implement the provisions and rules of the civil defense system whenever a disaster occurs. The LEC is chaired by the Emir of the region. It is composed of eight members (the director of the local police, the Commander of the National Guard in the region, the Director of Transportation in the area, the Branch Manager of the Electrical and Industrial Ministry of the region, the Branch Manager of Municipal Affairs 
and Rural Area, the Civil defense director of the area, the Commander of the Military Survey, and the Branch Director of the Ministry of Finance). The (LEC) convenes whenever it is necessary to deal with a crisis situation. However, such meetings are not held on a regular basis. Being a military organization, the GDCD adopts a top-down approach that is quite rigid and too much centralized as far as the decision-making process is concerned. In cases of disasters, a bottom-up approach in decision-making, flexibility and delegation of authority to people at the local level are essentially required. Rescuers and people tackling a disaster do not always have enough time to wait for decisions to be made by those at the central level.

Another issue with disaster management in Saudi Arabia can be attributable to the role assigned to the civil defense department with regard to flash flooding disasters. This role is defined by the Royal Decree No. M/10 of 20-01-1986 as:

"A set of measures and actions necessary for protecting the citizens, public and private properties from fire hazards, disasters, wars and different accidents plus helping devastated people, providing the safety of transportations, communications, and the best organizing in public utilities in addition to the protection of national wealth during the times of war, peace, and emergency situations".

It is clear from this statement that flash flood disaster is not in the priority list of the government agenda, as is the case with fire hazards which are more common in the country. One may also conclude from the above-mentioned definition that disaster management in the Saudi context is simply a matter of response and relief operations as it does not include any proactive or preventive provisions against the devastating impacts of disasters. Rescue and relief operations are essentially undertaken by official bodies such as the Civil Defense, the police, other security personnel, the National Guard, and the military. It is also clear that the Saudi Civil Defense approach in dealing with disaster situations focuses more on traditional structural measures to control and contain the disaster situation rather than managing it. The following section elaborates more on this issue.

\subsection{The issue of control and containment of flash flooding}

The current practice of adopting a reactive rather than proactive approach, has led the Saudi Civil Defense to focus more on structural measures to reduce runoff by controlling the flow of water, or limit the impact of flash flood on population through emergency response and flood recovery. The emphasis is, therefore, more on control rather than management. The literature insists on an alternative approach of integrated flash flood management policies. This modern concept of management embraces pre-emptive ways to make life sustainable even in flood prone areas and floodplains, and even when there is risk to life and property (WMO, 2009). The integrated flash flood management combines water resource management, land use management and hazard management. It insists on managing flood risks and learning to live with them. This concept shifts the flood management paradigm from a defensive to a proactive approach (WMO, 2009). This is precisely what the Civil Defence authorities in Saudi Arabia ought to adopt. The World Meteorological Organization projections suggest that in the future there will be an increase in the frequency and magnitude of flash floods and a wider distribution of flood events as a result of climate change. It is therefore crucial that such an integrated management should not be the exclusive concern of official bodies only but the whole community as well should get involved in the process. What role is assigned to the community is what is discussed in the following paragraph.

\subsection{The Issue of Community Participation}

Although the local emergency committee (LEC) includes representatives of different city departments (the military, the police, the civil defense, the different ministries...etc.), it does not have room for representatives of the local community, which constitutes a serious blow to public participation. Although the GDCD takes notes of the International reports, such as those of the International Institute for Sustainable Development - Reporting Services Division (IISD-RS), specifically the periodical reports of the Earth Negotiations Bulletin (ENB) Vol. 25, No. 15, 2015 regarding this issue, the GDCD code does not have any provision for the involvement of the 
local community as clearly specified in such reports from a management perspective. However, the GDCD's published mandate (referred to above as the Royal Decree) conceptualizes participation only in the form of volunteering of individuals during disaster response field operations. However, it has just recently activated the role of individual volunteers, allowing the public to be part of rescue operations during disaster events. According to this initiative, individuals can register their personal details online to be contacted when needed. Their role is therefore, restricted to mere response tasks. In many instances of recent disasters in Saudi Arabia, volunteers within the communities affected have provided a great assistance in relief operations, a participation that was largely acknowledged. However, those volunteers are reported to be individuals who happen to be present in the affected areas by chance. They were neither registered nor part of any voluntary organization perse.

The fact that the Government considers itself the sole guardian of the state, little room has been given to community participation. It has adopted a top-down approach where planning and decisions are taken by higher authority levels. This type of management does not seem to be appropriate for some managerial tasks where flexibility, quality achievement, quick coordination and effectiveness are most required as is the case for disasters management.

Recently, during the 2015 flash flood event, the Riyadh city administration authority, not to be confused with Riyadh Civil Defense authority, launched an application (Figure 1) that can be downloaded freely on smartphone devices allowing for online reporting of hazardous places and getting instant messages, hence allowing for information dissemination and sharing.

Although there are inter-departmental general outlines of what needs to be done during a disaster event, the authors could not find or get access to either short or long-term comprehensive risk strategies or action plan materials in which the roles of all stakeholders including the local population are pre-defined and prioritized. Long-term strategy would add to the resilience of the city to recover quickly in the aftermath of a disaster. This sharing of plan making and decision taking will assist in mitigating the city and community vulnerability, reducing the financial burden on the government, ensuring that

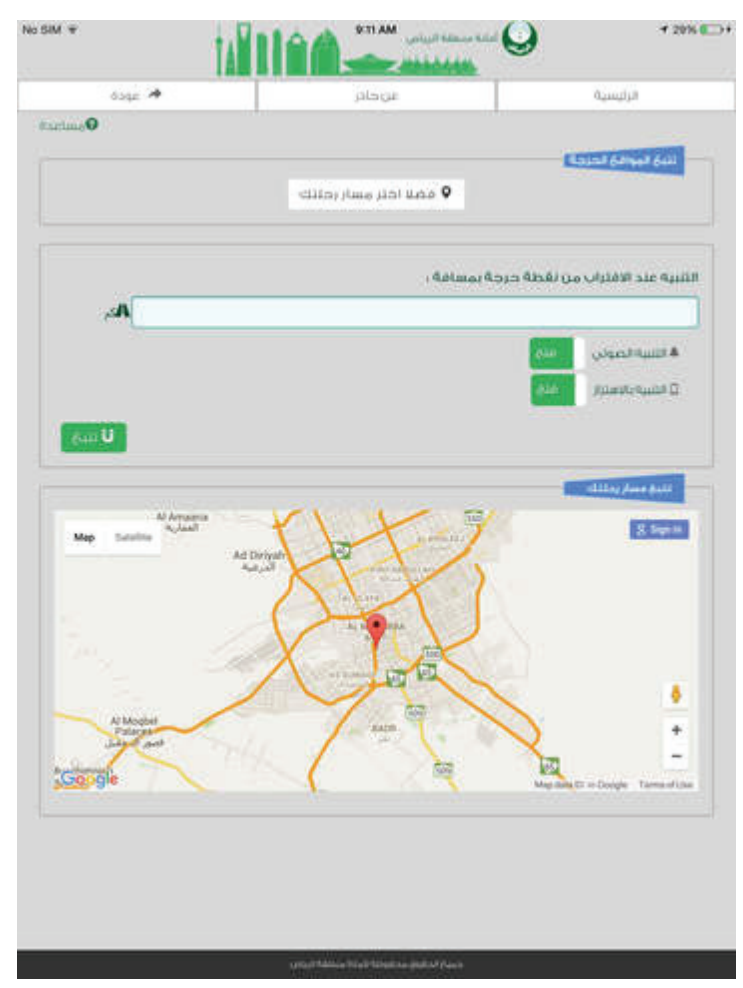

Figure 1. An Arabic language application named Hathir (Be Careful) designed by the Riyadh City Admin. Authority for people to report hazardous places online.

development funds are not relocated and assisting in recovering faster from the effects of a disaster.

The input of local communities and organizations is crucial in alleviating the disaster impact, especially on vulnerable populations. No one can provide a lot of information about the local setting, where vulnerable individuals are located and what their urgent needs are, and how to get to them, better than the members of the local community itself. It is therefore safe to say that no disaster can ever be dealt with effectively only through administrative set-up without the proactive participation of the community itself. Disaster management is not the responsibility solely of government or few institutions; it is the duty of everyone in the community. As they have experienced so many such flash flood events before, the local communities have accumulated a lot of knowledge and gained a good deal of practices in negotiating such events. It is therefore essential to get local people involved in every step of the process of flash flood management starting from risk identification, issuing early warning, setting up priorities for actions, formulating management plans, and implementing and 
evaluating such plans. Community participation is vital with regards to understanding vulnerability and long term risk management. Involving the community in risk identification, planning and management would not only enable the joint development of adequate measures and plans but also provide a sense of collective responsibility for mitigating vulnerability and risk.

Not only should local community get involved in flash flood management, but also its local knowledge should also be documented, archived and recorded to be analysed and used for future flash flood management. Such knowledge should be mapped to be used more efficiently and effectively. Participatory GIS mapping of hazards has proved to be a very helpful means in local knowledge recording. This is the subject matter of the next section.

\subsection{The Issue of Mapping and Participatory GIS (PGIS)}

Although mapping and participatory GIS can play a role of great value in either rescuing affected populations or planning of new development to reduce the impacts of disastrous events, we could not find a solid proof in the form of published documents that both disaster mapping and PGIS being an important tool for disaster management, except what is published in academic research documents. This does not however negate the fact that maps are, in general, important tools in planning in Saudi Arabian cities. When asked about disaster mapping and participatory GIS, the Civil Defense officers interviewed declared that they do not have such tools yet. They only have some printed maps or digital non-interactive ones. This weakness can have some negative impacts on the process of disaster management. They acknowledge the use of disaster mapping and Participatory GIS can help city managers analyse all the city areas for vulnerability and risk. Mapping therefore, facilitates the interpretation of hazard information, its dissemination and use in the decision-making process.

No proper hazard planning can be achieved without mapping, especially utilising the spatial technology such as GIS. Literature on GIS-based disaster management is abundant, as early as the late nineties (e.g., ESRI, 1999; Mileti, 1999; Sharma, 1999; Gunes and Kovel, 2000; Johnson, 2000; Jankowski and Nyerges, 2001a; Brail and
Klosterman, 2001; Greene, 2002; and MacEachren, et al., 2005).

The effective participation in flash flood management does not only require the involvement of the local community in planning, rescue and relief operations, but also the use of the local knowledge in the management process itself. As they have been there for generations, local people have dealt with similar disasters many times over. As a result, they have acquired a lot of knowledge that has been passed on from one generation to the next.

By integrating local knowledge and practices and available information with digital spatial databases of the area prone to hazards, participatory GIS (PGIS) produces more informative hazard maps, and helps greatly in providing a decision making tool for management of flash flood disasters. PGIS provides a communication platform between the local community and various government agencies. As such, sharing community knowledge with different stakeholders becomes more feasible and accessible. This approach of governance does in fact empowers local people; since they bear their own share of responsibility of the decision-making process (e.g., Pickles, 1995; Abbot et al., 1998; Craig and Elwood, 1998; Harris and Weiner, 1995, 1998; Obermeyer 1998; Craig et al., 2002). All this would encourage even further the active participation of local population in emergency response, planning and management. Although there is some progress, GIS mapping capabilities are unfortunately either not appreciated or not properly used at various levels of authorities responsible for disaster management in Saudi Arabia. This issue is explored more below.

\subsubsection{The Issue of Local flash flood hazard mapping}

Almost all Saudi cities, with the exception of Mecca to some extent, don't have updated flash flood hazard maps. The Riyadh Civil Defense Department has not yet established such a map for the city. The authors tried tirelessly to get a flood hazard map for Riyadh from this department but in vain. Unlike the local Civil Defense Department, the Riyadh High Commission for Development, uses GIS and recently produced a map showing critical areas that have been affected by the 2013 flash flood event (Figure 2). However, this map was produced after the event. It did not result from a proper modelling but merely by manually digitising 
the danger zones spotted on the ground, and it is only in the form of geometric shapes. The map was therefore not shared, except for internal uses. Assuming its acceptability, such a map is supposed to be produced for the on-going management of the disaster event, and be timely shared by all parties.

On the other hand, the General Directorate of Civil Defense (GDCD) does not treat maps as being a core decision making tool. In fact, the word 'Map' was barely mentioned in the documents that we could manage to get access to. Although the GDCD is supposed to have access, at least to all national databases, a visit recently made to their main computer servers, revealed the absence of geo-databases.

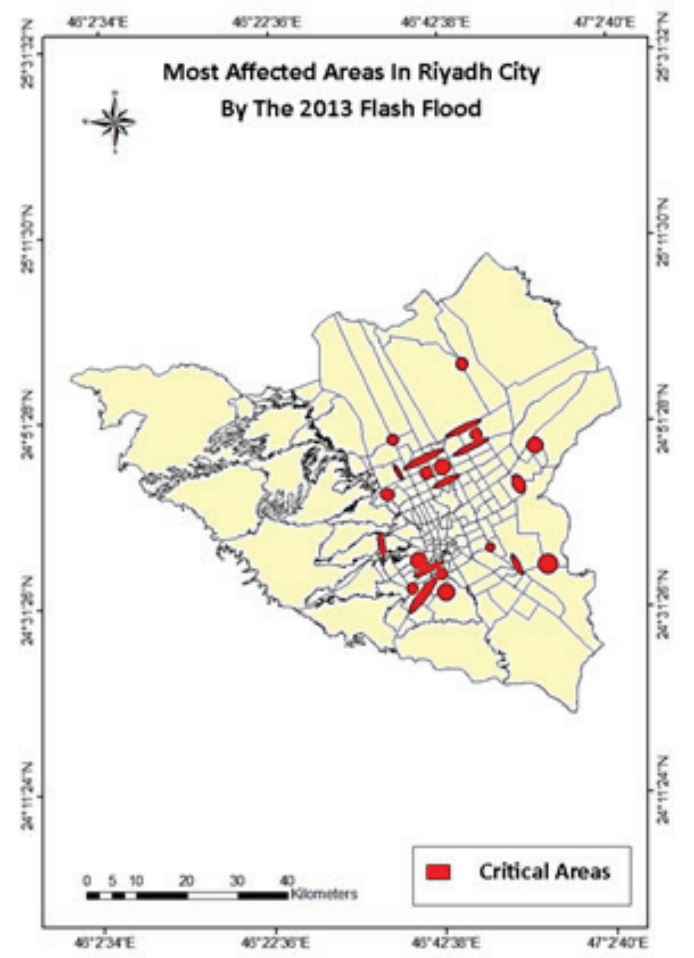

Figure 2. Most affected areas (critical areas) in Riyadh as manually digitised after the 2013 flash flood. Source: Ar-Riyadh Development Agency (ADA) 2014).

To establish a local flash flood hazard map, a lot of information about the range of possible damage such flooding can inflict to Riyadh community is required. Such information mapping is necessary to plan for the likely hazard scenario to alleviate the extent of the possible damage. The inexistence of such hazard mapping has led to the absence of other equally important maps showing possible safe evacuation routes, safer temporary settlement sites, shelter infrastructures, the location of vulnerable houses, vulnerable people, service delivery organizations, public security points, health centres, food depots and the location of the control unit. The precise indication of these elements on a map will help to quickly identify the location of the vulnerable groups and individuals like women, children, and people with disabilities or special needs, the elderly, and the like. The flash flood map hazard should also indicate areas that are particularly flood prone with high, medium, or low risk flood zones. The community should be well aware of such maps together with the contingency plans established for the eventuality of a possible flash flood. Obviously, the mapping process necessitates the collection, handling and storage of reliable data about flash flood disasters. This issue is further discussed in the following section.

\subsubsection{The Issue of Flash Flood Disaster Data}

Although data collection, storage and handling are critical to prepare for future scenarios about flash flooding in any area, the Civil Defence Departments, at the country level, do not seem to attach much importance to this issue. Little effort has been done regarding data collection, monitoring, and other associated systems, such as gathering and observing hydrological data, rainfall intensity, and stream flow. Researchers studying the issue of flash floods in Riyadh were often confronted by helplessness to run simulation, modelling and forecasting analyses to prepare for future scenarios and examine possible alternatives, and this is simply because of lack of data from these departments (CDs) as well as from other national departments which are supposed to hold reliable databases. One possible explanation for lacking of data, GIS and hazard mapping production, is that the Civil Defence Departments deal with disasters from a response perspective and, therefore, do not seem to be concerned with the issue of management as being a comprehensive concept where response is only one part of a four-stage process. Nevertheless, the response stage itself cannot be managed properly without data or maps. Whether the emergency control site or unit, usually set up during disaster events only, use of mapping technology is a matter that cannot be verified. It was impossible for the authors to get access to either its specific functions or related materials. Nevertheless, based on personal communication 
with some Riyadh Civil Defence officials, the only information the authors can report is that such an emergency unit is only temporary and not supported by proper mapping technologies and infrastructure.

Moreover, the reliability and validity of the information gathered are questionable, which makes the maps generated less useful. The timeliness and accuracy of information are critical for flash flood disaster management. A more detailed account of this issue is highlighted in our previous work (Ledraa \& Al-Ghamdi, 2014), in which we stated the severity of low quality geodatabases and their provision.

The problem of disaster management in Riyadh, as well as other places in Saudi Arabia, is compounded by the non-availability of historical flash flooding hazard GIS-based data which is necessary for the analysis of hazard trends. Even worse, lowlands, vulnerable population and exposed assets to flash flood risk are not even mapped and quantified. Such type of data can only be gathered and used within GIS environment by researchers. Unfortunately, most of the academic research production is also not properly referred to or utilised by non-academic institutions. This in itself is a critical issue which is beyond the scope of this article.

As stated earlier, the issue for arid zones like Riyadh is not much with riverine flooding but flash flooding. What is critical here to gather in terms of data is not the rainfall amount but the rainfall intensity. If for riverine floods, the total amount of rainfall during a period of time is of importance, the intensity of rainfall is more significant than the total amount for flash floods. Rainfall intensity data are crucial for flash flood forecasting or modelling. The amount of rainfall (not its intensity) is the most widely used measure in Riyadh. Manual rain gauges are most often used to assess rainfall amounts. This method is not enough to measure rainfall intensity; as a rain gauge gives only a point measurement at a particular location. What is required for the flash flood estimation is volume of water discharge for each drainage catchment. A dense network of rain gauges is therefore needed for such a case. Unfortunately, this type of spatial data is lacking in Riyadh meteorological data centre. For this reason, researchers in the country are only left with conducting their own measurements and modelling.

There is also the issue regarding the inconsistent data collected from various sources by different agencies and institutions. Despite the efforts of the newly formed governmental body, the General Directory of Surveying, which was intrusted to build the central national geodatabase, current practices of data collection by various agencies and departments have led to many problems related to data use, and handling and analysis. It is important therefore to speed up the work on this national geodatabase as soon as possible, and be shared by all government and non-government bodies and individuals. Achieving proper technical links between any emergency management centre and this central database as well as other national databases is equally important. Such centres are then supposed to carry out all technical work necessary to ensure a proper data integration.

\subsection{Challenges to Flash Flood Management in Riyadh}

There are many challenges to flash flood risk management in Riyadh city. Among such challenges are poverty-stricken city residents, poor and sometimes absence of reliable hydrological data, lack of information about rainfall and runoff intensity and magnitude, lack of policies for flash flood risk management, inefficient institutional mechanisms to deal with flash flood disasters, and paucity of coordination among government agencies and stakeholders at different levels of government.

The rapid urbanization in Saudi Arabia in the past four decades, has not only led to disrupting the natural drainage systems, but also to widespread impervious surfaces exacerbated by the lack of proper or damaged sewer system, which in turn has resulted in an unprecedented increase of storm water runoff (cf. Al-Saleh, 1997).

Sharif, et al., (2014) showed the effect of the urbanization process in Riyadh. A host of methods and measurements of hydrologic and hydraulic data were used along with various urbanization scenario simulations. Applied to a selected water catchment within the city, the study found a mismatch between the administrative and catchment boundaries. This clearly indicates the severity of urbanization process on the natural water flow, specifically its connectivity, hence the increased impact of flash flood risks as well as the difficulty of the hazard management process.

The rapid urban growth of Riyadh further increases the vulnerability of urban residents to the impact of flash flooding hazards. The growing 
numbers of the urban poor living in concentrated areas in high-risk zones are particularly vulnerable to flood hazards due to urban decay, dwindling infrastructure, and lack of adequate enforcement of building codes. With urban development unable to keep up with rising demands, the vulnerability of people and city infrastructure, the higher costs incurred in both human lives and economic assets raise the question regarding the effectiveness and preparedness of disaster risk management in Riyadh city.

In a recent study, Nahiduzzaman, et al., 2015 examined flood induced vulnerability in the strategic plan making process of Riyadh city. This is to evaluate the credibility of master plans with reference to the MEDSTAR comprehensive strategic development initiative to find out the resilience power against flash flood driven adverse consequences. The study took both the social and physical vulnerabilities into account, where GIS modelling was undertaken. The study found that many areas of the city, that are already proposed for specific land uses, expansion or densification, are either highly or moderately vulnerable to flash flood risks. Such a result highlights the importance of re-evaluating existent master plans as well as development strategies especially from the hazard vulnerability perspective. Addressing such challenges is best discussed within the typical phases of disaster management. This is outlined below.

\subsection{Disaster Management Phases}

Flash flood disaster management involves a cycle with four inter-related phases: Pre-flood management which entails two main phases: mitigation and preparedness; Post-flood management includes two other phases: response and recovery - short and long-term recovery and redevelopment (cf. Twigg, 2004). A comprehensive flash flood disaster management should take into account management issues at the above-mentioned four phases. Each phase faces different challenges and has its particular needs, and requires its distinct tools, strategies, and resources (Table 1). The table only includes selective sets of major tasks within each phase that we feel should at least be adopted in a disaster management plan. The most important matter however in flood disaster management phases is the availability of the proper and timely data and information required for decisions making processes and actions (e.g., Miranda et al., 1988, Okamoto et al., 1998; Rao, et al., 2013).

\subsubsection{The Issue of Disaster Management Mitigation}

The flash flood management process should start well before an unfortunate event occurs. This phase is aimed at reducing vulnerability to disaster impacts such as injuries and loss of life and property. As to the case of Riyadh, the local civil defence department does not seem to attach much importance to this phase. The reason may lie in the lack of proper collection and use of data of past flash flood disasters in the city. As these flood events are not commonplace in the area, concern about mitigating their impacts tends to be replaced by a sense of complacency. This explains to a large extent why no major revisions of local urban zoning ordinances and land use management are made, for example to avoid construction in risk-prone areas such as low laying lands. No amendments of building codes have been introduced to reinforce structures to resist the devastating impacts of flash floods. Such amendments are crucial to building city resilience against hazardous events such as flash flooding. Zoning ordinances still do not prevent buildings in low laying areas. Building codes have

Table 1. Disaster Management Phases.

\begin{tabular}{|c|c|}
\hline $\begin{array}{l}\text { Mitigation } \\
\text { - Zoning regulations } \\
\text { - Building Codes } \\
\text { - Vulnerability Assessment } \\
\text { - Public Education } \\
\text { - Improved Infrastructure }\end{array}$ & $\begin{array}{cl}\text { Preparedness } \\
\text { - } \\
\text { - } \quad \text { Training \& Drills } \\
\text { - } \quad \text { Early Warning } \\
\text { - } \quad \text { Public Information }\end{array}$ \\
\hline $\begin{array}{l}\text { Recovery } \\
\text { - Aid Organisation } \\
\text { - Housing and Medical Assistances } \\
\text { - Infrastructure and Business Restorations }\end{array}$ & $\begin{array}{l}\text { Response } \\
\text { - Relief \& Rescue Operations } \\
\text { - Information Dissemination } \\
\text { - Warning Systems } \\
\end{array}$ \\
\hline
\end{tabular}


not been modified to strengthen structures. The only planning bylaw that has been promulgated concerns non-permission of building in water streams or riverbeds. It must be stressed that riverbeds in desert areas are dry most of the time. In some cases, there were low laying lands in Riyadh that were previously designated as open areas and parks for recreation, have been changed to commercial and office buildings use. Many other old buildings in risk-prone areas were demolished but to be rebuilt for newer residential and commercial structures. They should have been rezoned for other uses than residential such as recreation or any other use that does not expose people's lives to flood risks. Medium to long term sectoral planning where a focus is put on building resilient city infrastructure is yet to be established. Measures to enforce building codes and zoning laws to inhibit the generation of risks are yet to be promoted. Revision of building codes should in fact be introduced with reference to the topography of the city.

In Figure 3, a DEM for Riyadh was developed, the major wadi (in light blue) as well as other minor wadis and streams on the left are visible on the ground, while other streams on the right are mostly not visible on the ground, as a result of ground leveling for urban development and

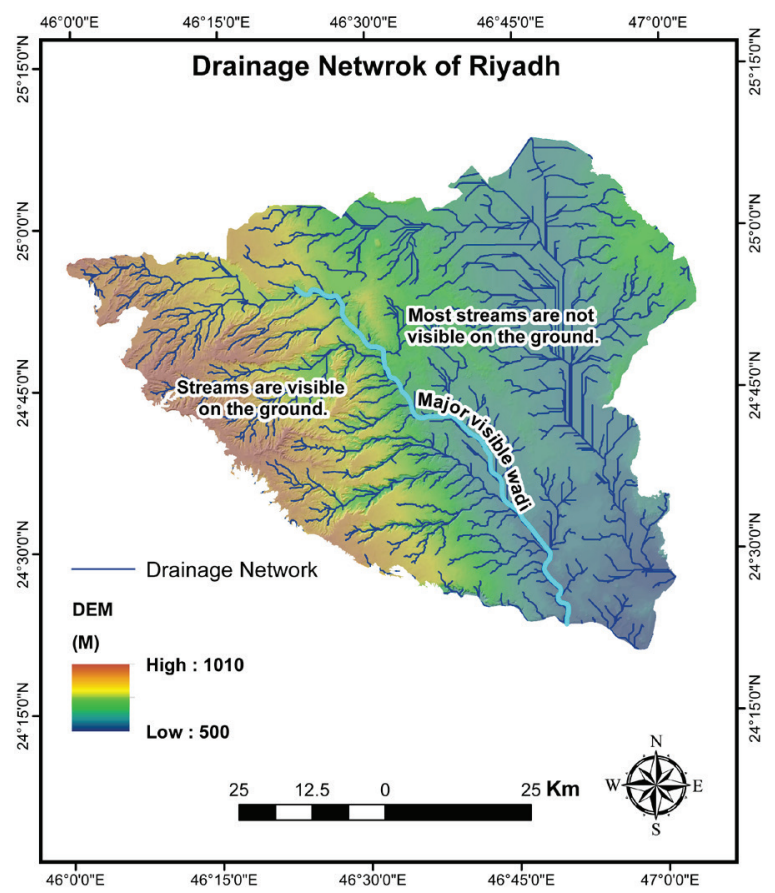

Figure 3. A DEM derived drainage network of Riyadh. construction, leading to severe disruption of their natural water flow. In Figure 4, the terrain surface (left) clearly shows two major natural drainage directions (in blue) crossing the city due south. However, most parts of these natural wadis are no longer visible on the ground, as their flows are either directed or terminated. The second map on right of Figure 4, shows an entire neighbourhood (An-Nadheem) laying in the lowest elevation of the city, which has incurred the most devastating impact of the 2013 flash flooding, as it received the water flow (in blue) from different directions. This map (on right) shows current directions of streets, clearly with no reference to contour line directions.

\subsubsection{The Issue of Disaster Preparedness}

In the most recent study, Rahman, et al., 2016 presented their GIS-based methodology adopted for their previous study (Nahiduzzaman, et al., 2015). They explained how their vulnerability indices were developed and mapped. The resultant map showed that the low-lying central and southern half of Riyadh city is highly vulnerable to flash flood, which is a densely populated area where low-income families live. Their identified area, although based on social as well as physical criteria, appear to support our judgment based on the maps in Figure 3 and Figure 4.

Much of Riyadh vulnerability to flash flood disasters can be attributed to its deficiency in preparedness. The city lacks the establishment of flood zone maps describing city areas in terms of flood risk levels (low, moderate, or high risk). These maps are crucial as they indicate which properties are most at risk of flooding and those that are less at risk. Such information would allow resource allocation and rescue personnel deployment in a faster and more efficient way.

Management at the preparedness phase involves a focus on building community resilience to be able to alleviate disaster impacts. It consists of being prepared for a disaster situation well before it occurs. Besides the flood zone maps, the city should also have a business recovery plan to be effected once a disaster is over. Unfortunately, both the proper flood zone maps and the business recovery plan do not seem to have a priority in Riyadh's authority agenda. Riyadh local authorities have not made much effort to enhance the community preparedness. Little community 

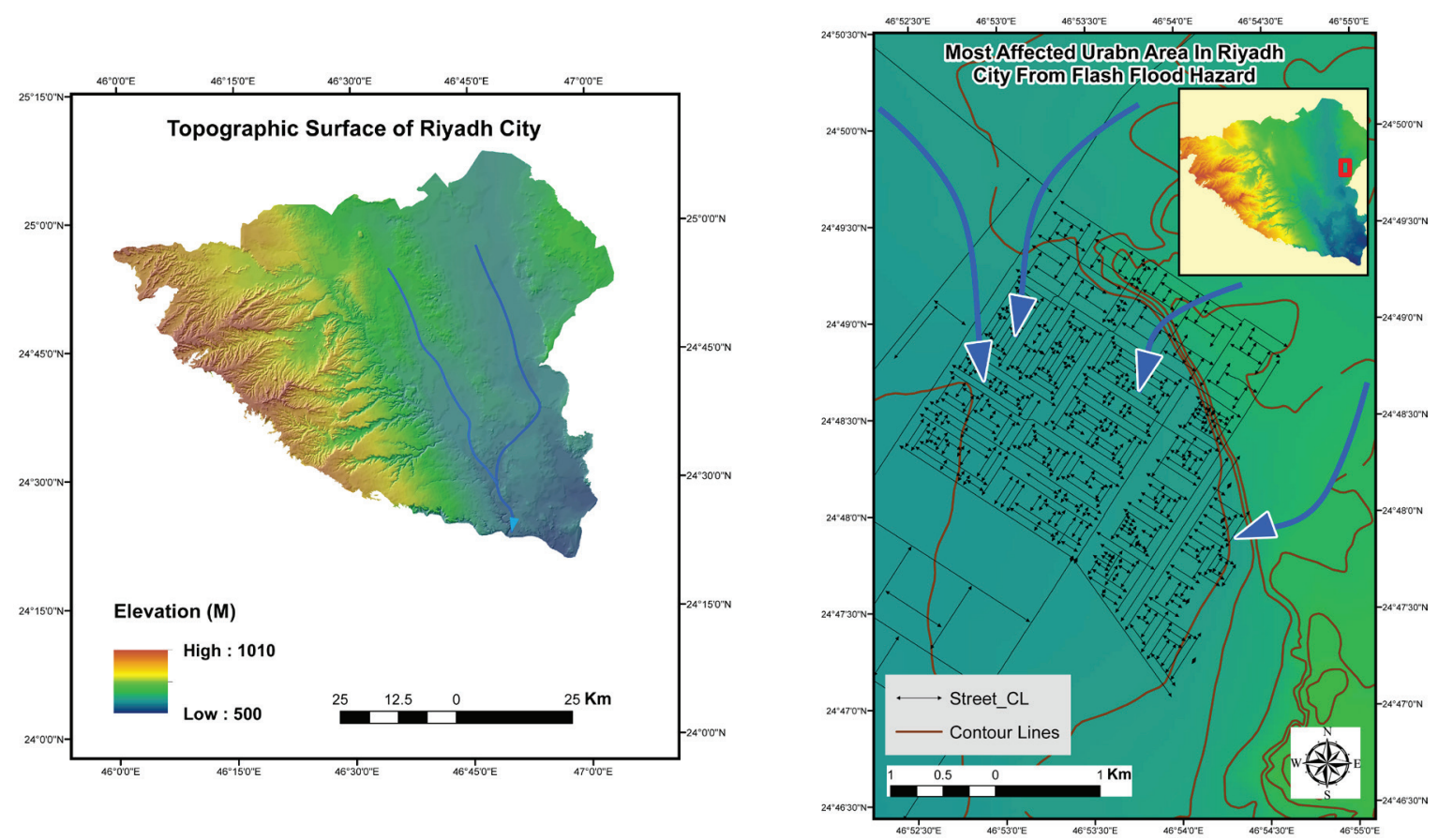

Figure 4. Topographic surface of Riyadh city shows two major natural water flow directions crossing the city. As a result of urban development however, their physical existences is missing in most parts of the city (Left). A whole neighborhood (An-Nadheem) is built on a low-lying land (Right). .

education campaigns, if any, are organised and little or no outreach and training efforts are planned to increase the city's capacity to respond to and recover from a disaster. In fact, being unaware of which danger zones a residents live in, which is a result of miscommunication between the city authority and the locals, is in itself a case of mismanagement. Although some efforts are being made, they still fall short of efficient management standards. It is therefore safe to conclude that lacking of a proper and comprehensive management plan would lead to uncoordinated efforts, focusing on one management phase at the expense of the other phases.

By simply adhering to their mission statement as cited earlier, the Riyadh Civil Defence Department insists more on disaster relief than disaster preparedness. Relief operations are first and foremost a task assigned to the Civil Defence personnel, the military and the police. Rarely has the local community been engaged in the process. The Riyadh Civil Defence Department and the Riyadh city authority do not yet have a pre-disaster strategic planning, nor do they prepare logistical readiness activities. Even the businesses are seldom prepared to restore their activities as soon as possible after a disaster. Since such flood disasters are uncommon in Riyadh, local authorities are getting somewhat complacent. As such they do not see the establishment of a pre-disaster economic preparedness plan as a matter of urgency. Lack of such plans would mean that the business community and stakeholders will not know the roles and actions to be taken to spur the recovery process should a disaster occur.

Riyadh authorities have yet to keep an inventory of the trained human resources available in case of emergency. Even a permanent emergency operation centre (i.e., control room) has yet to be properly established. The Civil Defence records have no mention for identified safe places nor for evacuation should a disastrous flash flooding event occur.

Although better communication and information dissemination have recently been developed, public awareness has yet to reach a desired level in Riyadh. Awareness messages sent to the public through multimedia like newspapers, radio, television, mobile phones, and internet, to enhance community preparedness during the pre-disaster phase are still not very common nor always accurate. Proper and well organized 
preparedness training and drilling in disaster response for community groups and institutions as well as public information campaigns are uncommon in Riyadh which does not help to keep the community aware of what to do at the onset of any disastrous event.

\subsubsection{The Issue of Early Warning system}

The issue of early warning does not seem to have a priority in Riyadh disaster management. The fact that flash flooding has a short lead time, it is quite difficult to predict and hence difficult to announce public warnings for such events. The little effort to increase public awareness may be attributable to the fact that the GDCD insists more on disaster response and relief rather than preparedness.

When asked about the existence of a central unit connected with all agencies and organizations, the GDCD personnel said they do not have such a unit. They even complained about the reluctance of other departments to transmit the required information willingly on time. Although the Civil Defence government decree specifically insists on the Local Emergency Committee (LEC) to join representatives from all government agencies, the weak coordination between these agencies greatly hampers the activation of such a unit. The exclusion of non-government organizations, local community and other stakeholders from taking part in this unit may further impede the early warning measures. The local community and voluntary organizations are much closer to the population affected so they can be more trustworthy and hence more reliable and faster in spreading the warning messages and instructions.

Since Early Warning Systems (EWS) consist of a set of measures related to preparedness to disasters well before they occur, a setup of an appropriate physical centre fully equipped with all necessary apparatus for the LEC to operate its early warning tasks. During our interviews we were told about the existence of a meeting room commonly set up during disaster events, usually called "Emergency Operations Room". But since we could not access such a unit or some of its personnel, it was difficult to present more details. We were left therefore to stress what should be available from a normative stand point.

For a better efficiency, early warning should not be confined to receiving and sending warning messages only, interactive maps should be prepared well in advance to be used in time of disaster. Preparedness and proactive plans should also be pre-established to deal with any flash flood hazard prior to its occurrence. This is precisely what is lacking in the case of Riyadh Local Department for Civil Defense (LDCD). Early warning $(\mathrm{EW})$ is crucial in the sense that it leads to boosting prevention, mitigation and preparedness which in turn lead to disaster risks being reduced. For this purpose, emergency planning measures should be defined, simulation drills and exercises carried out, vulnerable population must be known beforehand, as well as the risk prone areas, places where affected people would be assembled, evacuation routes to be taken between the affected areas and the rescue zones... etc. All this information is necessary otherwise the success of early warning system would be limited.

In cases of flood disasters, the Presidency of Meteorology and Environment (PME) sends a warning message 12 hours prior to the expected event to the Civil Defense Department (CDD) at the central level to pass it on to its administration at the local level which in turn transmits the information to all local government agencies. Each agency works according to its predefined contingency plans. In theory, there should be some sort of coordination between them. The Local Department for Civil Defense (LDCD) and the security personnel with their equipment are then deployed where necessary especially in places considered as hazard prone areas. Field operations usually include various tasks, such as rescuing, sheltering, repairing, routing and bridging or removing water. Once the flood disaster is over, each government agency prepares a report to its respective higher administration of what, where and why the damage has occurred as well as making some recommendations. As they are independently written, some inconsistencies are usually revealed in the reports. This is due to a deficiency of coordination between different agencies and government bodies.

\subsection{The Issue of Poor Urban Infrastructure and Planning}

The issue poor infrastructure has a lot to do with the exacerbation of flash flooding disasters in Riyadh. Reports following each flood disaster have repeatedly revealed either the absence, insufficient or poor construction of storm sewer 
ducts. The reasons might be due to the lack of or insufficient financial resources, poor planning and/ or poor implementation. The problem is worsened by the fact that projects are not carried out within a single government entity. For example, some projects are entrusted to the local municipalities, others to the Ministry of Municipal and Rural Affairs (MOMRA) while others to the Ministry of Transport. Each entity has its own planning requirements and implementation standards which make coordination difficult and in some cases even impossible. This poses questions as to how urban planning and decisions are exercised within the city.

In addition to the poor storm sewer drainage system, most of the old tunnels (e.g. in Jeddah city) were constructed in a way that they follow the topographic slope from highlands to lowlands, following the natural direction of waterways. These tunnels should have been in the opposite direction of the natural slope to slow down the flow speed of flood water (Al-Alami, 2011). This orthogonal form of plan layout, where the topographic terrain was not taken into account, is to blame for the aggravated problems of flash flood hazards.

Prompted by the effects of the recent disasters, decision-makers in Riyadh decided to rehabilitate the natural watercourses in the city, especially in places where many parts of old waterways have disappeared to become new built-up areas. This should incur a thoughtful list of actions top of which are expropriation and drainage projects. Currently, there are concerted efforts to initiate and implement many water drainage projects in most cities of Saudi Arabia.

\subsection{The Issue of Flash Flood Risk Management Measures}

Flash disasters cannot be prevented from occurring but their devastating impact can be to some extent curtailed. Any management objective to eliminate the flooding adverse impacts would be unrealistic. The feasible objective would rather be to tolerate some sort of flash flood risk up to a certain level and manage to live with. The focus should not be on how to stop flash flooding but how its adverse impacts could be averted through careful adopted management measures to reduce susceptibility to flood damage. Riyadh does not yet have a City Disaster Management Authority (CDMA) under this specific name, but only a Civil Defense department for the city under the umbrella of the GDCD -just like all other cities in the country. Moreover, we found no evidence that Riyadh has a published City Disaster Management Plan (CDMP). If such an authority is set up, it is crucial to adopt proper management approach and infrastructure. In many cases, the Local Emergency Committee only convenes during the disaster event, the researchers however attempted in vain to search for minutes of any of such meetings, only news reports about when and where such meetings are held. These management measures such as land use planning and floodplain zoning and regulation, housing and building code enforcement, structure management regulations, land acquisition policies, awareness and preparedness campaigns, and information dissemination, flash flood early warning systems are therefore required to reduce flash flood risks. It is therefore important for flood prone areas to be delimited, mapped, secured and regulated to prevent or mitigate most of the damage that might be inflicted.

Land use management consists of regulating settlements and building in flood prone areas. Development must be restricted in flood zones so as not to put people at risk and not to alter the watercourse and the natural flow of water. Such land use control and regulations would reduce danger to life and property assets. These measures could be reducing residential density in some flood prone areas or preventing development in areas that present higher risks.

Watercourse maintenance is one of the issues that matters in flash flood management. In most cases, the topography of the terrain has not been respected to a point where watercourses were being landfilled and built upon. This has caused a lot of damage to buildings and property assets each time a flash flood occurs. The main issue here is not only the fact that natural watercourses are not respected but they also lack regular maintenance.

Another issue lies in the fact that when cleaning roads and draining ducts from all sorts of debris and sand, maintenance workers often clean only light sand dust leaving larger wreckage and hard remains like soil and mud where they are. When a flooding occurs, the drainage system gets blocked. The becoming debris-laden flood gets then an even more increasing devastating force.

In some parts of the city, particularly in low-income neighbourhoods where lower classes of the society are settled, street cleaning from 
rubbles is not very common. Drainage systems in these areas get blocked very easily because of lack of regular maintenance. Many companies when undertaking some work, tend to leave the rubbles as they are, which may cause the obstruction of flood water drainage ducts. The situation is worsened even further when many drainage channels are not designed to cope with the runoff intensity which lead to water overflow on the street as is the case in many parts of Riyadh.

\section{Conclusions and Recommendations}

From the above discussion, few major findings can be summarized as follows:

- It is safe to conclude that the problem does not lie with the flash flood disaster per se as much as it does with the management approach adopted. The centralized top-down approach seems to have shown some serious limitations in reducing the risks of flash flooding. It is therefore, important to embrace a more decentralized bottom-up approach to management that adheres to the principles and benchmarks of local (stakeholders) participation, accountability and quality assurance.

- Currently, the issue of disaster management in Riyadh City is essentially a matter of relief and response operations undertaken mainly by the military and security personnel. Such stand point needs shifting towards a more inclusive view of disaster management in which the involvement of the local community in the process would be a must. Unfortunately, little has been done so far to build community trust to secure the public participation in disaster management. Lack of effective intra-departmental communication and coordination contributes to the problem of alienating the local community. This makes the decision making process slow, which badly affects both the speed and quality of response to disasters. Effective coordination and community participation are therefore of paramount importance in an emergency situation.

- With recent trends showing an increasing frequency and intensity of natural hazards, there is a greater need to focus more on building city resilience. Riyadh Civil Defense disaster management system ought to make a significant shift from a relief-driven response to a more proactive approach, with an emphasis on disaster prevention, mitigation and preparedness.
- Better yet, we propose that it is time to establish a National Civil Disaster Management Agency (NCDMA), similar to those in many countries. The role of this Agency would be about regulation and governance only, where Local Civil Disaster Management Departments (LCDMDs) can be established where and when necessary. Having established a single civil local body that is properly functional, it should take care of all management steps and requirements before, during and after disasters. As such, the roles of other government and non-government bodies shall be redefined in accordance with state-of-the-art disaster management approaches. Accordingly, the role of the current Civil Defense Department, which is under a civil military authority, is confined to response activities only, while other civil departments should be assigned other respective roles and according to the four management phases. With such a single unit and mandate, it is quite possible to find proper strategies, data, maps, personnel, hence effective management not only for flash flood disaster but all types of disasters. This means that the LCDMD personals, in each region or city, are always on-duty, focusing on establishing and applying Disaster Management Plans (DMPs). Such an institutional arrangement and planning will enable each city, for example, to actually have a long-term disaster risk management and build capacities to enhance city resilience against flash flood disasters or other types of disasters. It will also help quick decision-making in a short time frame, improve coordination and collaboration among stakeholders to mobilize resources and manage relief operations. This is the main point to be raised.

- Spatial and non-spatial data on both the national and local level should be collected, stored, managed and updated according to the best practices in the developed world. Data about past disasters, for example, should be collected, stored and analyzed, and lessons must be drawn and used to improve operational capabilities to cope with future disasters. Risk prone areas and vulnerable population in the city must be identified, mapped, and for which detailed disaster management plans must be established. Such an exercise would be crucial for the city authorities to pinpoint in advance the neighborhoods, blocks and populations that are more prone to risk, thereby requiring immediate intervention. Any infrastructure deficiencies would also be identified and dealt 
with promptly.

- Being a hot research topic either now or in the foreseeable future in Saudi Arabia, there is a need for conducting further studies, preferably major joint or inter-disciplinary and institutional studies.

\section{References}

Abbot, J., R. Chambers, C. Dunn, T. Harris, E. de Merode, G. Porter, J. Townsend, and D. Weiner. (1998). Participatory GIS: Opportunity or oxymoron. PLA Notes 33: 27-34.

Al-Khalaf AK, Basset HA. 2013. Diagnostic study of a severe thunderstorm over Jeddah. Atmospheric and Climate Sciences, 3:150-164.

Almazroui, M. 2013. Simulation of present and future climate of Saudi Arabia using a regional climate model (PRECIS). Int. J. Climatology., 33: 2247-2259. doi: 10.1002/joc.3721

Almazroui M. 2011a. Sensitivity of a regional climate model on the simulation of high intensity rainfall events over the Arabian Peninsula and around Jeddah (Saudi Arabia). Theor. Appl. Climatology., 104:261-276

Al-Alami, F. (2011， 2 1). Jeddah's Rain More "Intelligent" than its Experts (Arabic). Retrieved 11 25, 2013, from alwatan newspaper: http://www.alwatan.com. sa/Articles/Detail.aspx?ArticleID=4259

Alamri, Y. (2010) Emergency Management in Saudi Arabia: Past, Present and Future. In: McEntire D. A. (Ed.) Comparative Emergency Management: understanding disaster policies, organizations and initiatives from around the world. Federal Emergency Management Agency, (FEMA), USA.

Al-Saleh, M. (1997). Variability and Frequency of Daily Rainfall in Riyadh, Saudi Arabia. The Geographical Bulletin. Retrieved from http:// www.gammathetaupsilon.org/the-geographical-bulletin/1990s/volume39-1/article5.pdf

Brail, R., and Klosterman, R. (2001). Planning support systems: Integrating geographic information systems, models, and visualization tools. Redlands, Calif: ESRI Press.
Coleman, H. S. (1988). Social Capital in the Creation of Human Capital. The American Journal of Sociology (Supplement) 94, S95-S120.

Coleman, J. S. (1990). The Foundations of Social Theory. Cambridge: Harvard University Press.

Craig, W. and S. Elwood. (1998). How and Why Community Groups Use Maps and Geographic Information. Cartography and Geographic Information Systems 25(2): 95-104.

Craig, W. J., T. M. Harris and D. Weiner, eds. (2002). Community Participation and Geographic Information Systems. London: Taylor and Francis.

ESRI. (1999, 7). GIS for Emergency Management. ESRI White Papers. CA, USA.

FEMA. (2011). A Whole Community Approach to Emergency Management: Principles, Themes, and Pathways for Action. FDOC 104-008-1 / December 2011

Greene, R. W. (2002). Confronting Catastrophe: A GIS Handbook. Redlands: ESRI Press.

GulfNews, (November 17, 2015). Flash floods turn deadly in Jeddah. URL: https:// gulfnews.com/world/gulf/saudi/flashfloods-turn-deadly-in-jeddah-1.1621189

Gunes, A. E., and J. P. Kovel. (2000). Using GIS in Emergency Management Operations. Journal of Urban Planning and Development, 126 (3):136-149.

Haggag M, El-Badry H. (2013). Mesoscale numerical study of quasi-stationary convective system over Jeddah in November 2009. Atmospheric and Climate Sciences, 3, 1:73-86. doi: 10.4236/acs.2013.31010

Harris, T. M., D. Weiner, T. Warner, and R. Levin. (1995). Pursuing Social Goals Through Participatory GIS: Redressing South Africa's Historical Political Ecology. In Ground truth: The social implications of Geographic Information Systems, ed. J. Pickles, 196-222. New York: Guilford Press.

Harris, T., and D. Weiner. (1998). Empowerment, Marginalization and Community-integrated GIS. Cartography and Geographic Information Systems 25(2): 67-76. 
iNewsArabia. (2013, 11 20). International Report: Natural Disasters in the Middle East Have Increased Three Folds (Arabic). Retrieved 11 25, 2013, from iNewsArabia: http://www.inewsarabia.com/551/

Jacobs, J. (1961). The Death and Life of Great American Cities. New York: Random House.

Jankowski, P., and T. L. Nyerges. (2001a). Geographic Information Systems for Group Decision Making: Towards a Participatory Geographic Information Science. New York: Taylor \& Francis.

Johnson, R. (2000). GIS Technology for Disasters and Emergency Management. An ESRI White Paper, May 2000.

Ledraa, T., \& Al-Ghamdi, A. (2014). A Review of Flood Hazard Planning and Mapping Within the Context of Saudi Arabia. Proceeding Vol.2, 5th ICC\&GIS 2014 (pp. 699-700). Varna: Bulgarian Cartographic Society.

MacEachren, A. M., G. Cai, R. Sharma, I. Rauschert, I. Brewer, L. Bolelli, B. Shaparenko, S. Fuhrmann, and H. Wang. (2005). Enabling Collaborative Geo-information Access and Decision-Making Through a Natural, Multimodal Interface. International Journal of Geographical Information Science, 19 (3):293-317.

Ministry of Higher Education (2015). Atlas of Kingdom of Saudi Arabia. 2d Edition. Riyadh: Ministry of Higher Education.

Miranda, F., Fonseca, L. and Carr, J., (1988). Semivariogram textural classification of JERS-1 SAR data obtained over a flooded area of the Amazon rainforest. International Journal of Remote Sensing, 19, pp. 549-556.

Nahiduzzaman, K., Aldosary, A., and M. Rahman. (2015). Flood Induced Vulnerability in Strategic Plan Making Process of Riyadh. Hibitat International, 49, 375-385. doi:doi: $\quad$ 10.1016/j.habitatint.2015.05.034

Newport, J.K. and G. G. Jawahar. (2003). Community Participation and Public Awareness in Disaster Mitigation. Disaster Prevention and Management, 12(1), pp.3336. Emerald Group Publishing Limited.
Obermeyer, N., ed. (1998). Special issue: Public participation GIS. Cartography and Geographic Information Systems, 25(2).

Okamoto, K., Yamakawa, S. and Kawashima, H. (1998). Estimation of flood damage to rice production in North Korea in 1995. International Journal of Remote Sensing, 19, pp.365-367.

Pickles, J., ed. (1995). Ground Truth: The Social Implications of Geographic Information Systems. New York: Guilford Press.

PME, P. o. (2011). Second National Communication: Kingdom of Saudi Arabia. Jeddah: Presidency of Meteorology and Environment (PME).

Putnam, R. D. (1995). Bowling Alone: America's Declining Social Capital. Journal of Democracy, 6(1), 65-78.

Rao, S., Bhatt, CM., Manjusree, P, Sharma, S., Asiya Begum. 2013. Flood Monitoring and Management Using Remote Sensing. Bulletin of The National Natural Resources Management System, (B) - 38. Available from: https://www.researchgate.net/publication/260754231, [accessed May 27 2019].

Rahman, M. T., Aldosary, A. S., Nahiduzzaman, K. M., \& Reza, I. (2016). Vulnerability of Flash Floodinig in Riyadh, Saudi Arabia. Natural Hazards. doi:DOI: $\quad 10.1007 / \mathrm{s} 11069-016-2521-8$

Sharif, H. A., Al-Juaidi, F., Al-Othman, A., Al-Dousary, I., Fadda, E., Jamal-Uddeen, S., and Elhassan, A. (2014). Flood Hazards in an Urbanizing Watershed in Riyadh, Saudi Arabia. Geomatics, Natural Hazards and Risk. Retrieved 9 10, 2016, from http:// dx.doi.org/10.1080/19475705.2014.945101

Sharma, V.K.(1999). Use of GIS Related Technologies for Managing Disasters in India: An Overview. New Delhi, India: National Center for Disaster Management, Indian Institute of Public Administration. Report is available from: http:// www.gisdevelopment.net/application/ natural_hazards/overview/nho0003.htm

Twigg, J. (2004). Good Practice Review: Mitigation and Preparedness in Development and Emergency Programming. Humanitarian Practice Network (HPN), Overseas Development Institute, London. 
UNISDR. (2005). Hyogo Declaration. World Conference on Disaster Reduction. 1822 January 2005, Kobe, Hyogo, Japan

WMO, (2009). Integrated flood management: APFM Concept Paper. Geneva, Switzerland: World Meteorological Organization, Associated Programme on Flood Management. 


\section{إدارة وتخطيــط كـــوارث الفيضانــات في المملكـــة العربيــة الســـودية: قضايــا وتحديــات. مدينـة الريــاض كحالـة دراسـية}

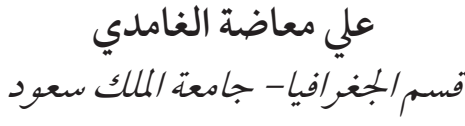

aghamdi1@ksu.edu.sa

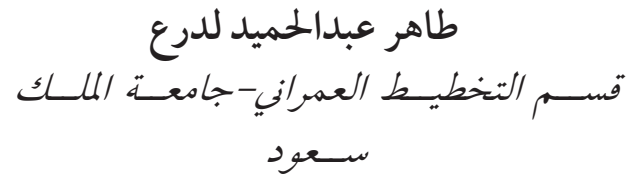

tledraa@ksu.edu.sa

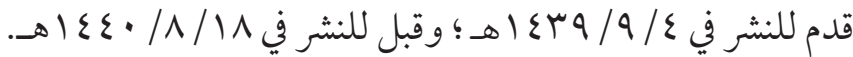

ملخص البحث. يستعرض البحث القضايا والتحديات التي تعترض تخطيط وإدارة كوارث الفيضانات الفجائية في مدن المملكة العربية السعودية من خلال دراسة حالة مدينة الرياض. إن تزايد وتيرة وخطورة هذا النوع من الكوارث في مدن المملكة جعل من مسألة إدارة الكوارث والتخطيط ها أحد اهتمامات السلطات

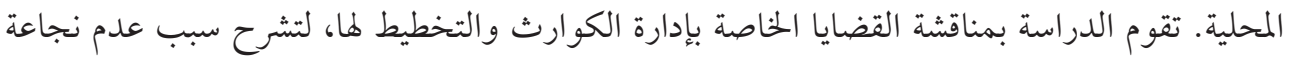
الأساليب المتبعة حتى الآن في التعامل مع هذه الكوارث وما ينبغي القيام به للحد من تأثيراتها السلبية. وقد

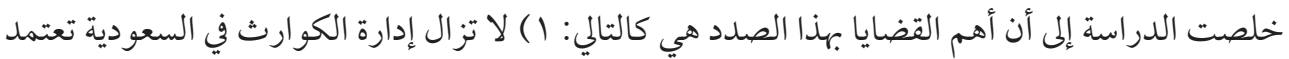

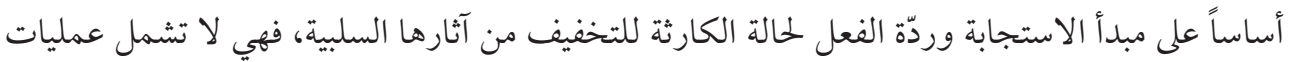

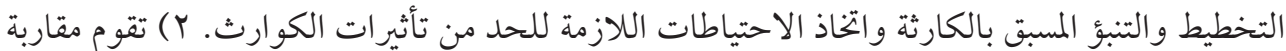
السلطات المعنية بإدارة الكوارث بالدرجة الأولى على مجرد الإحاطة بالكارثة و التعامل معها للتقليليل من آثارها بدل إدارتها. ؟r) لا تتوفر السلطات المحلية على استراتيجية واضحة المعالم وذات الخطط التنفيذية المحددة للتعامل مع الكارثة وإدارتها. ع ) لا تمثل تقنيات جمع البيانات وإعداد الخر ائط التفاعلية (تقنية نظم المعلومات

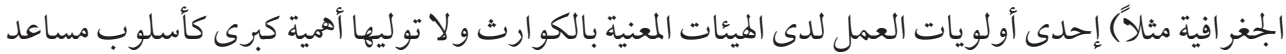
لاتخاذ القرارات السليمة. تخلص الدراسة إلى ضرورة تبني إدارة شاملة ومتكاملة للكو ارث تقوم على المراحل الأربع المعتمدة في مثل هذه الحالات، وتضمن مشاركة المجتمعات المحلية في العملية. كما ينبغي أن تتسم هذه إنها العملية بالمرونة والشفافية والمحاسبة والفعالية. وتقترح أيضاً ضرورة إقامة وحدة مركزية لإدارة الكوارث وتزويدها بكل التجهيزات لتعمل على جمع البيانات ومعالجتها وتحليلها ونمذجتها ونشر المعلومات لكل لمكل الجهات والأطراف المعنية. كما يتعين إشر اك المجتمع المحلي في كل العملية خلال جميع مر احلها. الكلمات المفتاحية: إدارة الكوارث، الفيضانات الفجائية، الحالات الطارئة، المشاركة الشعبية، الخرائط، نظم 